\section{Marija Idžojtić}

Škola primijenjene umjetnosti i dizajna Osijek / School of Applied Arts and Design Osijek

Krbavska bb, Osijek

marrijakos@gmail.com

Izvorni znanstveni rad / Original scientific paper

UDK / UDC: 76 Sekler, E.

15. 6. 2015.

\title{
Osječki tiskar i grafički dizajner Eugen Sekler
}

Ključne riječi: Tiskara Ljudevit Sekler, Tiskara Eugen Sekler, grafički dizajn, modernizam, Exposition internationale des arts décoratifs et industriels modernes, Internacionalna izložba knjižne umjetnosti u Leipzigu

Keywords: Printing house Ljudevit Sekler, Printing house Eugen Sekler, graphic design, modernism, Exposition internationale des arts décoratifs et industriels modernes, International Book Fair in Leipzig

U članku se prikazuje segment opusa osječkog tiskara i grafičkog dizajnera Eugena Seklera koji dosad nije bio prepoznat u osječkoj likovnoj sredini, a tako ni kao relevantan akter hrvatskoga grafičkog dizajna, koji se obrazovanjem u Beču i Leipzigu uklapa u modernističke oblikovne trendove dvadesetih $i$ tridesetih godina 20. stoljeća. Zastupljenost na međunarodnim izložbama primijenjenih umjetnosti ide u prilog potrebi visokoga autorskog pozicioniranja unutar povijesti hrvatskoga grafičkog dizajna.

Zaboravljeni osječki tiskar i grafički dizajner Eugen Sekler dosad je ostao potpuno nepoznato ime u korpusu hrvatske povijesti grafičkog dizajna. Eugen je sin znamenitoga osječkog tiskara Ljudevita Seklera čija je tiskara djelovala od 1893. godine i u kojoj je odgojem upućivan na grafičku struku. Od najranijih je dana Eugen oblikovao grafička rješenja vizualnog identiteta za očevu tiskaru pa tako 1921. godine oblikuje memorandum tiskare koji predstavlja odlučan odmak od naglašenoga secesijskog tretmana prijašnjih akcidencija te tiskare, a na kojem je prvi put otisnut logotip Seklerove tiskare koji je Eugen oblikovao $\mathrm{u}$ vrijeme ili neposredno prije inozemnoga umjetničkog školovanja (sl. 1).

U kontekstu povijesti hrvatskoga grafičkog dizajna Sekler se izdvaja po kvaliteti grafičke naobrazbe i po interesu za tada još marginalna područja oblikovanja vizualnih komunikacija, nastala suradnjom dizajnera s industrijom - za dizajn znakova i logotipa, dizajn ambalaže i reklama, ali i za oblikovanje cjelovitih vizualnih identiteta koje je radio za osječke i zagrebačke obrtnike i industrijalce.
Znakovit je i njegov doprinos oblikovanju knjižne opreme i komercijalnih vinjeta. U njegovu se opusu međutim ne nailazi na rješenja za plakat kao dominantan reklamni medij. $\mathrm{Na}$ Seklerovu je primjeru razvidno da je grafički dizajn kao nova disciplina imao bazu u tiskarskom zanatu te da se novim zahtjevima industrije i masovnih medija, u spoju s dizajnerskim senzibilitetom pojedinih osobnosti, odvaja od njega.

Njegov opus predstavlja progresivan, hibridan umjetnički koncept koji se svodi pod pojam moderne. U njegovu su radu tako zamjetne ekspresionističke grafičke intervencije, no najvećim se dijelom priklanja vokabularu art décoa kao »manifestaciji modernizma, a ne konzistentnoj stilskoj formaciji ${ }^{1}$

U Zavičajnicima grada Osijeka 1901.-1946. doznaje se da je Eugen Sekler »rođen 6. veljače 1896. godine u Osijeku, od oca Ljudevita i majke Roze rođene Kohn «. ${ }^{2}$ U Povijesti tiskarstva u Slavoniji navodi se da je Eugen Sekler "pohađao višu grafičku školu u Zagrebu pa je kao vrlo talentirani grafičar osim za tiskaru svoga oca, radio i nacrte za razne zagrebačke tiskare. Radovi su mu reproducirani u Grafičkoj reviji te ga tamo tituliraju kao akademički grafik Eugen Se- 


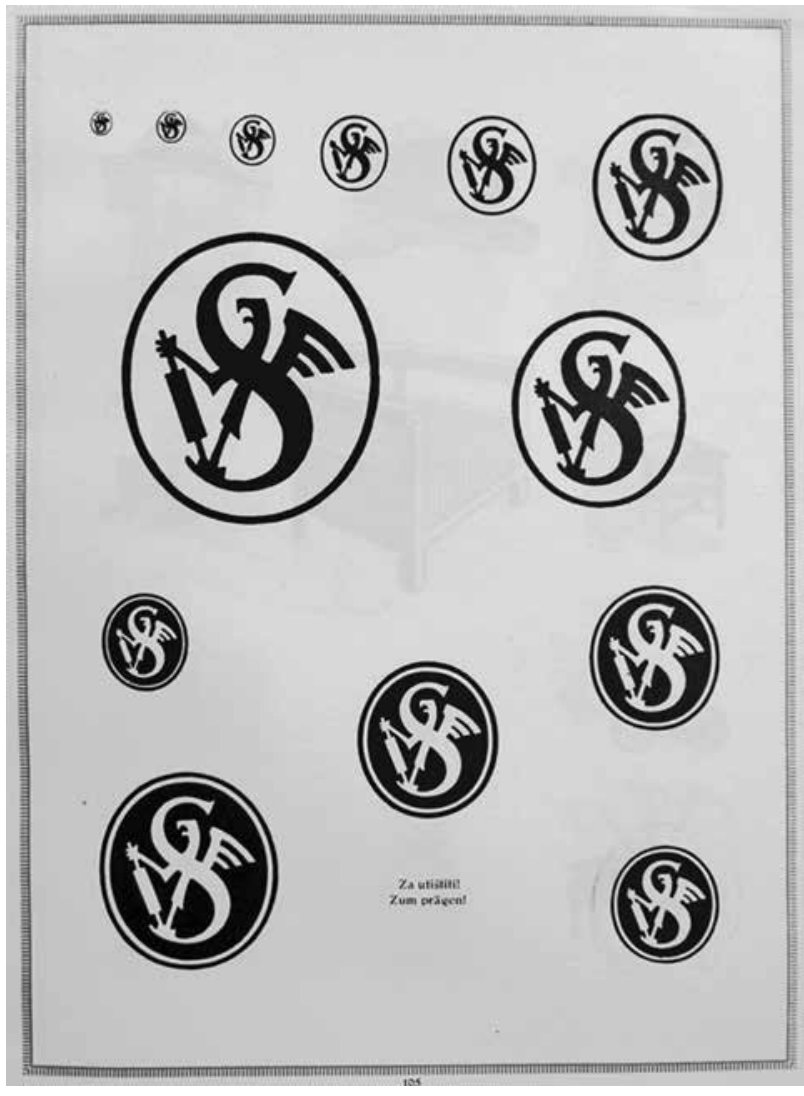

1. Eugen Sekler, Signet Tiskare Ljudevita Seklera, Katalog tiskare Eugena Seklera: Pisma, 1934., 1921. (Muzej Slavonije Osijek) / Eugen Sekler, Signet of Ljudevit Sekler's printing house, Catalogue of Eugen Sekler's printing house: Lettering, 1934, 1921 (Museum of Slavonia Osijek)

kler«. ${ }^{3}$ Takvo pak tituliranje, ipak, nije jamstvo da je Sekler uistinu i stekao diplomu akademskog umjetnika, a nema potvrde ni o Seklerovu zagrebačkom obrazovanju.

Izvjesno je pak njegovo akademsko obrazovanje i to na Akademie für graphische Künste und Buchgewerbe $\mathrm{u}$ Leipzigu, gdje je zabilježeno da je boravio od 18. listopada 1920. do 16. srpnja 1921. godine. ${ }^{4}$

Njegovo se obrazovanje dodatno rasvjetljava u upisnim dokumentima i korespondenciji ${ }^{5}$ koju je vodio s upravom Akademije, a kojom je u to vrijeme ravnao eminentni grafičar i tipograf Walter Tiemann. Sekler je odabrao leipzišku Akademiju, renomiranu po specijalizaciji u grafičkom prijelomu i knjižnom oblikovanju. Bila je tradicionalistički usmjerena i imuna na Bauhausovu tipografsku revoluciju, a upravo je Tiemann bio "predstavnik konzervativnog pristupa u tipografiji i oblikovanju knjiga, koji se suprotstavljao rastućoj uporabi modernističkog sans-serifnog pisma«. ${ }^{6}$

Pomoću Seklerovih odgovora na detaljno postavljena pitanja na prijavnici koju ispunjava za upis u akademsku godinu 1920./21., doznaje se kronologija njegova obrazovanja. Sekler navodi da je po zanimanju knjigotiskar (Buchdrucker) te da je to njegova željena struka. Saznaje se da živi u Beču gdje pohađa Graphische Lehr- und Versuchsanstalt, sve do leipziškog školovanja, jer od tamo šalje pisma na Akademiju.

U odgovoru na pitanje o dotadašnjem školovanju navodi da je maturirao na Trgovačkoj akademiji u Osijeku (Handelsakademie), preteči današnje srednje Ekonomske škole.

Nadalje, Sekler navodi da je apsolvirao na Export-Akademie u Beču, što bi odgovaralo apsolviranju na ekonomskom fakultetu. Na pitanje o umjetničkim i stručnim vještinama koje posjeduje, Sekler odgovara da su to kemigrafija, litografija i knjigotisak. Među odgovorima je i taj da stručno obrazovanje koje stekne na Akademiji namjerava primjenjivati u očevoj tiskari u Osijeku.

Sekler se pismom obraćao upravi Akademije već 7. lipnja 1918. godine upitom može li kao jugoslavenski državljanin konkurirati za upis na Akademiju odnosno bi li mogao upisati jednogodišnju specijalizaciju u knjigotiskarstvu (Buchdruck (Satz in Druck)) te postoji li mogućnost izvanrednog studiranja. Sekler ističe da ima praktično znanje u litografiji i kemigrafiji koje je stekao radom u očevoj tiskari, te apsolvirao u Beču na Graphische Lehr- und Versuchsanstalt, ali da je slab odnosno da se ne osjeća dovoljno iskusnim u knjigotisku koji namjerava usavršiti na njihovoj Akademiji.

Sekler ponavlja sličan upit i 1920. godine kada mu je odgovoreno da ga je prof. Georg Belwe, u europskim razmjerima iznimno cijenjen tipograf i grafički dizajner, spreman primiti u svoju klasu za Umjetnički slog i tisak (Künstlerischen Satz und Druck). Čini se da je Sekler, budući da su mu se priznali predmeti s bečke Graphische Lehr- und Versuchsanstalt, odmah primljen na 3. stupanj studija.

U prijepisu svjedodžbe (sl. 2) koju je zatražio nakon završene akademske godine 1920./21. piše da je kao redoviti student pohađao Akademiju u razdoblju od 18. listopada 1920. do 16. srpnja 1921. godine, uz izvrsnu motiviranost i dobar uspjeh. Dalje se navode stručni predmeti koje je slušao kod prof. Belwea: Oblikovanje sloga (Tipografija) (Entwerfen für Schriftsatz), s naglaskom na slovima, tipografiji; Primijenjena grafika (Gebrauchsgraphik), što bi odgovaralo grafičkom dizajnu; Plakat te Oblikovanje sloga i tisak (Schriftsetzen und Schriftdrucken), za što se danas uobičajio pojam grafička priprema ili priprema za tisak.

Izborni predmeti koje je slušao jesu: Umjetničko pismo (Kunstschrift) kod prof. Hermanna Delitscha; Knjigotisak (Buchdruck) kod V. Neuberta; Reprodukcija fotografija (Reproduktions-Photographie) kod prof. Ruperta Marchla; Umjetnička grafika (Kunstgraphik) kod prof. Zeitlera; Uporaba pisma i boja (Brief und Farbenüzen) kod Kirstena.

Sekler je popunio prijavnicu za pohađanje nastave i sljedeće akademske godine, dakle 1921./22., no čini se da nije nastavio studij.

Tvrdnja da se »Eugen Sekler vratio u Osijek 1928./'29. kada je preuzeo radnju svojega oca, i da tvrtka tada glasi Tiskara Eugen Sekler «" pokazala se netočnom jer je već 1926. 


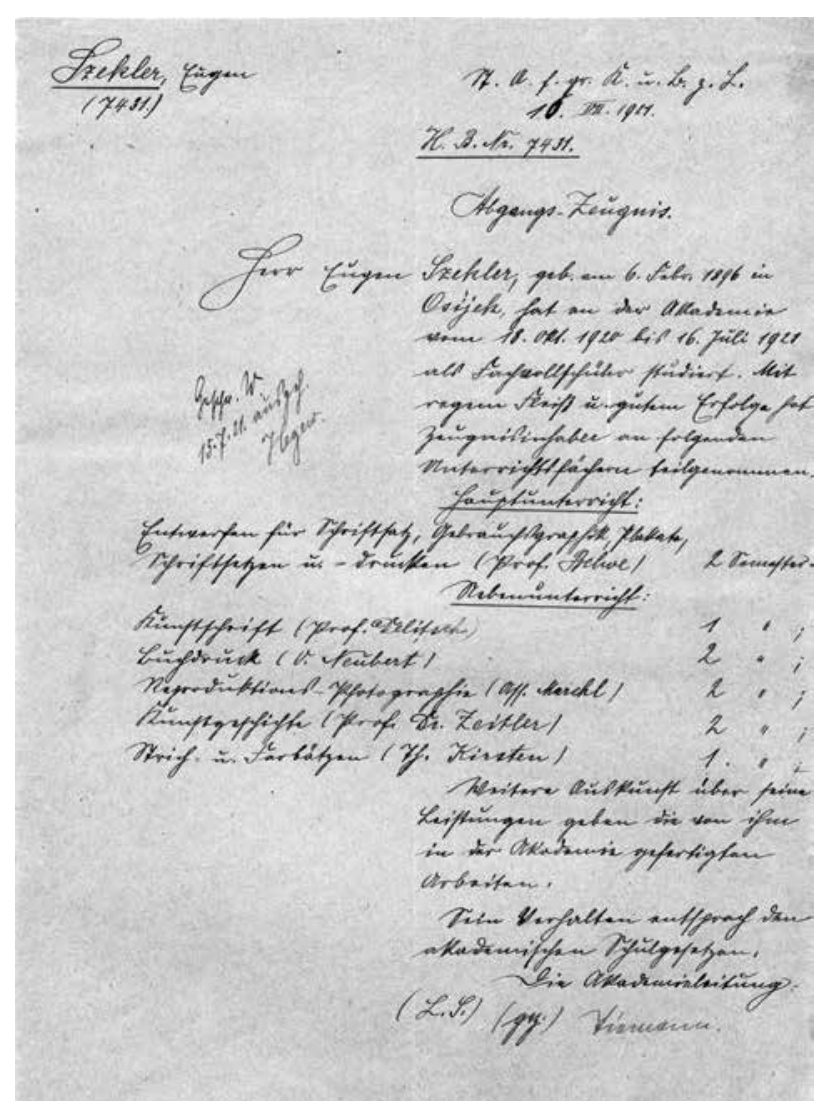

2. Prijepis svjedodžbe s Akademie für graphische Künste und Buchgewerbe Leipzig, 16. srpnja 1921. (Saechsisches Staatsarchiv Leipzig-No.136) / Transcript of a diploma from Akademie für graphische Künste und Buchgewerbe Leipzig, 16 July 1921 (Saechsisches Staatsarchiv Leipzig-No. 136)

godine Eugen Sekler upisan kao prokurist. ${ }^{8}$ Potvrda se o Seklerovu ranijem povratku u Osijek i djelatnosti Tiskare Eugen Sekler pronalazi i na memorandumu naslovljenom Tiskara Eugen Sekler, a riječ je o ponudi od 18. listopada 1927. koju on i potpisuje.

Zamjetna je simultana uporaba zasebnih računa i memoranduma naslovljenih na Ljudevita i onih naslovljenih na Eugena (pod okriljem iste tiskare), koja se provlači do posljednjih dana postojanja Seklerove tiskare. ${ }^{9}$

Tiskanice koje Eugen Sekler oblikuje za »svoju« tiskaru odnosno grafički zavod, kvalitetom se izdvajaju od tadašnje produkcije akcidencija u Osijeku jer njegova rješenja odlikuje modernistički racionalan i reduciran pristup u oblikovanju (sl. 3). Sekler prostor tiskanice tretira kao pravocrtnu mrežu u koju umeće linijske trake blistavih i decentnih boja, tekst i logotip. Logotip otiskuje u negativu, čak i u reljefnom tisku, čime pojačava luksuzni dojam tiskanice. Na tim osobnim tiskanicama varira i svoje omiljene fontove - isprva je to Magere Block, a potom Belwe Antiqua i na kraju Lo uski.

Posljednja je među tiskanicama naslovljena na Tiskara Eugen Sekler iz 1941. godine (sl. 4). Razdjelne linije otisnute

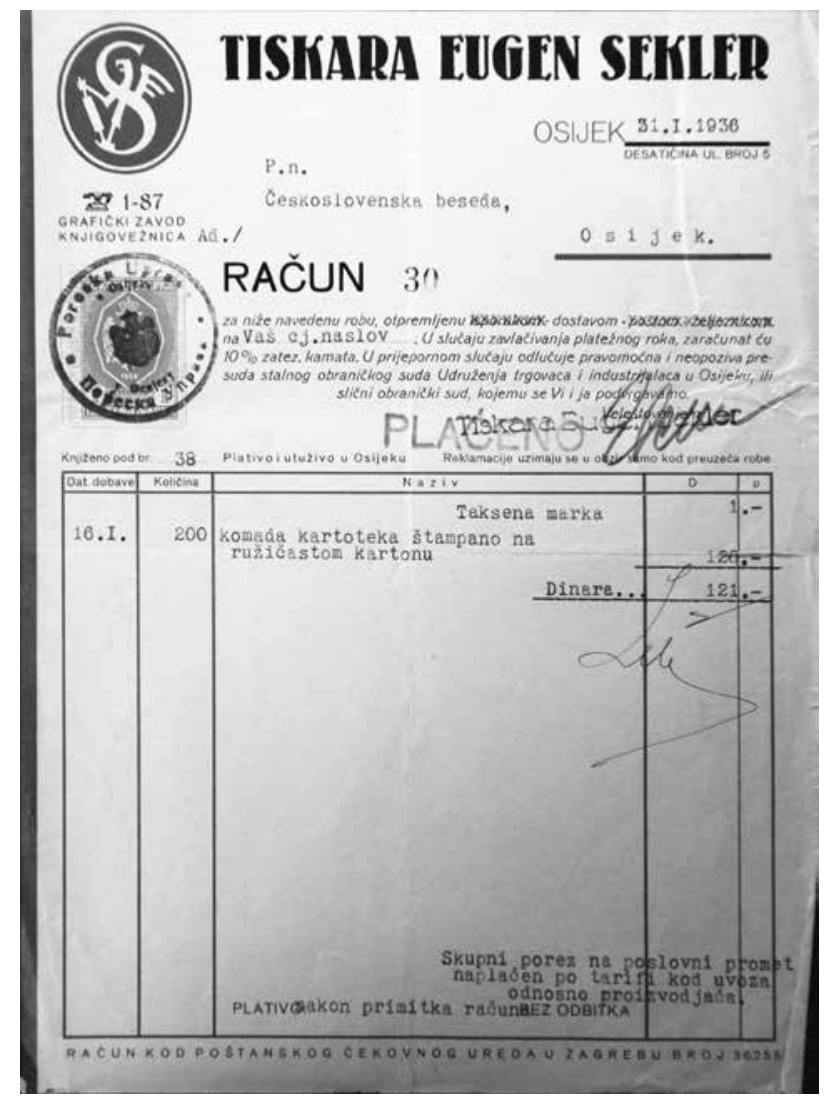

3. Eugen Sekler, račun, Tiskara Eugen Sekler, 1936. (HRDAOS-2090) / Eugen Sekler, receipt, Printing house Eugen Sekler, 1936 (HR-DAOS-2090)

su u kombinaciji boja - ili u narančastoj i srebrnoj ili u plavoj i srebrnoj boji. Tekst je pisan nekom od inačica Groteska. U zaglavlju tiskanice u pozitivu je otisnut logotip tiskare, a uz njega stojeća naga figura dječaka, putta, u trenutku kada na ramenu nosi kutiju s tiskanicama koje upravo ispadaju iz nje. Već je i prije njegov motiv bila figura dječaka mediteranskog izgleda. Čvrsto, deskriptivno vođena linija upućuje na Seklerov crtački talent i asocira na rješenja toga motiva čestog u secesijskom repertoaru.

Seklerova tiskara posluje sve »do 1941. godine, kada je konfiscirana kao židovska imovina, a kao povjerenik postavljen je Hugo Meister, koji već iduće godine postaje vlasnikom knjižare i papirnice, dok tiskara prestaje s radom ${ }^{10}{ }^{10}$

Tragična sudbina Eugena Seklera istovjetna je onoj većine osječkih Židova. ${ }^{11}$ "Iako je 31. listopada 1941. godine prešao na katoličku vjeru «, ${ }^{12}$ Sekler »umire u Osijeku 1942. godine od posljedica zlostavljanja ${ }^{13}$

Nakon leipziškog obrazovanja Sekler je, uz stalni angažman u tiskari svojeg oca, više godina boravio u Zagrebu. Na to upućuje velik broj Seklerovih radova koji su u razdoblju od 1924. do 1927. godine tiskani u Hrvatskom štampar- 


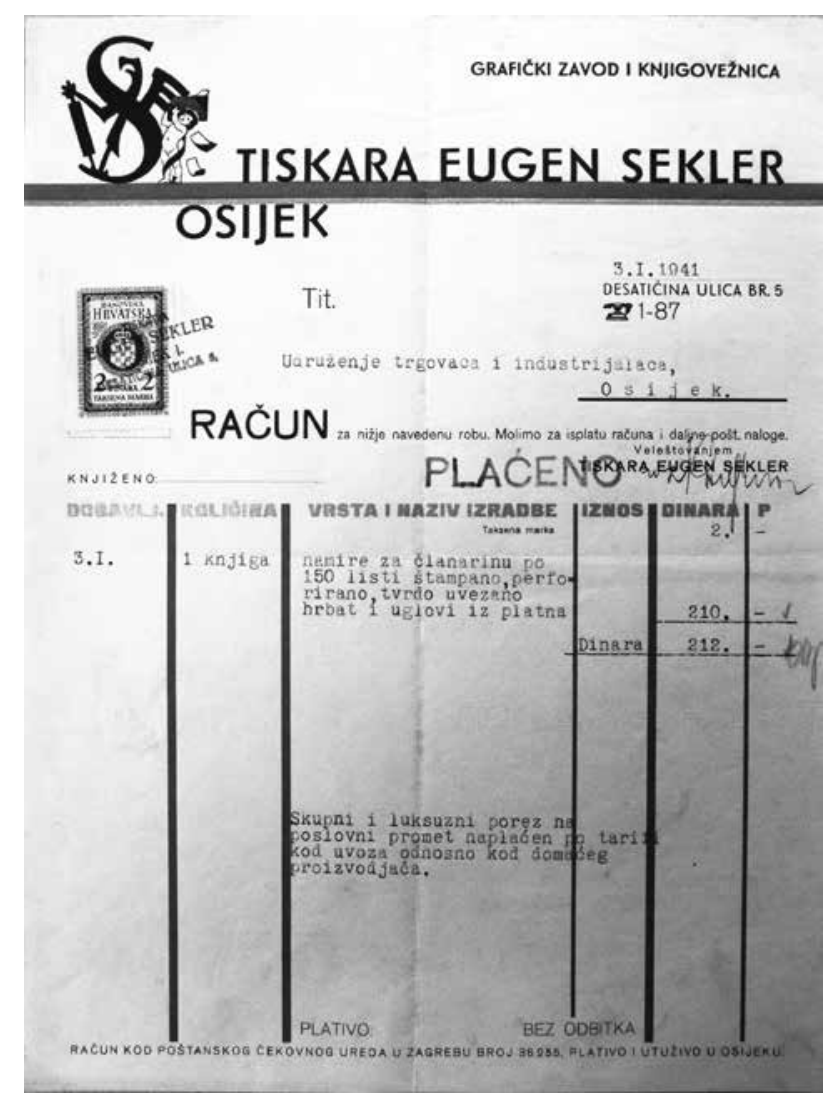

4. Eugen Sekler, račun, Tiskara Eugen Sekler, 1941.

(HR-DAOS-1371) / Eugen Sekler, receipt, Printing house Eugen Sekler, 1941 (HR-DAOS-1371)

skom zavodu d. d., Zagreb, ali i stalan teorijski i dizajnerski angažman vezan uz zagrebačku Grafičku reviju. Suradnja s Hrvatskim štamparskim zavodom konstanta je Seklerova rada jer se ona nastavlja i u kasnijoj osječkoj podružnici Zavoda, a obuhvaća grafički dizajn najrazličitije namjene, s naglaskom na oblikovanju knjižne opreme.

Najraniji rad iz »zagrebačkog« razdoblja naslovnica je prvog sveska časopisa Grafička revija iz 1924. godine (sl. 5). Taj je strukovni časopis neprekidno objavljivao natječaje za rješenja svojih naslovnica koju je stoga svaki put oblikovao drugi umjetnik odnosno tiskarski djelatnik. Crtež predstavlja golog dječaka naglašene muskulature, gledanog s leđa, koji kleči pred kutijom slagaćega tipografskog materijala i uzima odabrani element. Trenutak je sakralno ozbiljan, bez ikakve naznake dječje igre; osjeća se kao da dječak obavlja kakav posvećeni obred odabira. Takvom osjetilno sugestivnom vizualnom interpretacijom Sekler odaje poštovanje grafičkoj struci, a modernističko rješenje naslovnice sadrži raznorodna stilska obilježja. Nazubljena dekoracija oko figure odgovara ekspresionističkoj motivici u trendovima tipografskog oblikovanja, impostacija prikaza gledanog iz ukošene vizure i neugodno udaljenog od gledatelja te oštar

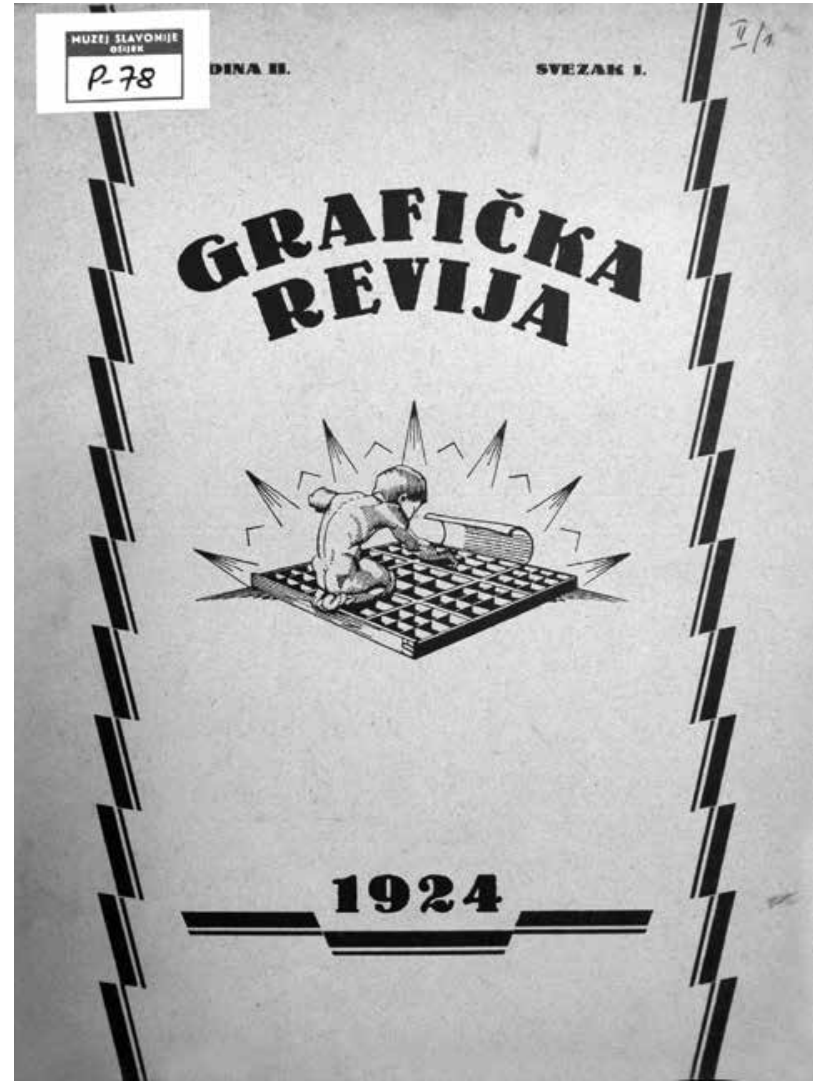

5. Eugen Sekler, naslovnica Grafičke revije, 1 (1924.) (Muzej Slavonije Osijek) / Eugen Sekler, cover of Grafička revija, 1 (1924) (Museum of Slavonia Osijek)

linijski grafizam odlike su koje upućuju na estetiku art décoa. Crtež karakterizira odmjerena i istančana kretnja linije, što je dominantna odlika Seklerova stila - u obrisu on je reduciran, a volumeni su potencirani šrafiranjem, što se uklapa u karakter nazubljenog ornamenta koji, s gornje strane, polukružno zatvara cijeli prikaz.

Slijeva i zdesna cijeli je prikaz flankiran grubom linijskom trakom koja je složena tako da tvori nazubljeni obris te se poput tračnica silovito proteže cijelom visinom naslovnice, vodeći naše oko sklisko preko nje. Taj je uznemireni dinamizam dominantna odlika toga rješenja, a naglašen je crnim otiskom na žutozelenoj podlozi. Takvo furiozno gibanje također je lajtmotiv artdécoovske estetike. Linijska je traka po masnom, ekspresivnom tijeku u suglasju s tekstom. Gornji dio naslovnice lučno zatvara tekst: Grafička revija, a pri dnu je krajnje stilizirana zastavica, građena od istih linijskih elemenata koja tvori postament za inskripciju godišta: 1924. Upotrijebljen je Lo masni, font po kojem je Sekler prepoznatliiv.

U tom su rješenju sadržane neke od osnovnih odrednica Seklerova stila koji je obilježen praćenjem aktualnih trendova u tipografskoj, tiskarskoj struci i uporabi komercijal- 


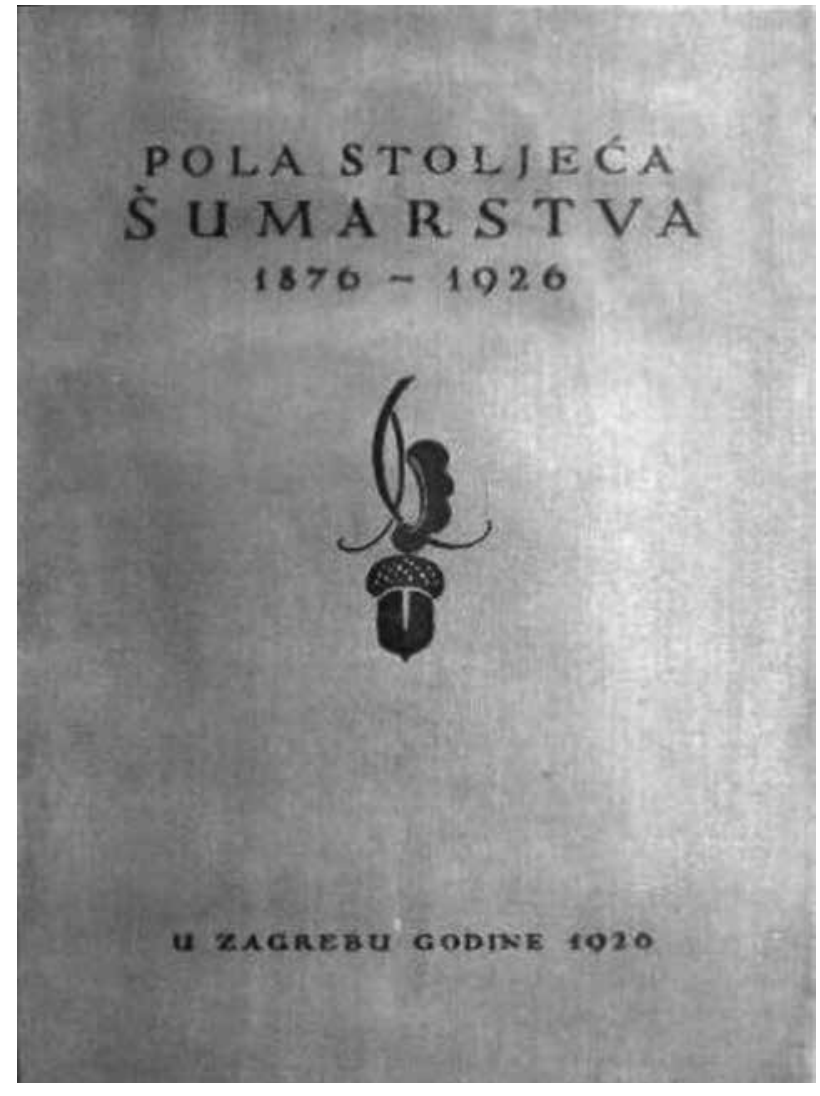

6. Eugen Sekler, korice knjige, Pola stoljeća šumarstva, 1876-1926; Un demisiècle d'activité forestière, 1876-1926, Mémorial de l'Union forestière Yougoslavè à l'occasion de son cinquantenaire, Hrvatski štamparski zavod, Zagreb, 1926. / Eugen Sekler, cover of the book Pola stoljeća šumarstva, 1876-1926; Un demisiècle d'activité forestière, 1876-1926, Mémorial de l'Union forestière Yougoslavè à l'occasion de son cinquantenaire, Hrvatski štamparski zavod, Zagreb, 1926

noga tipografskog materijala kojem je često i autor, a koji čini ekspresionistička ornamentika ${ }^{14}$ ili pak ona art décoa. $S$ druge je to strane pročišćen i discipliniran izraz koji se očituje u snažnoj, linearnoj stilizaciji formi, a upućuje na maniru art décoa.

U članku pod nazivom III. Zagrebački zbor (Sajam uzoraka), početkom 1924. godine objavljenom u Grafičkoj reviji, pohvalno se govori o radovima Hrvatskoga štamparskog zavoda u Zagrebu, izrađenima prema nacrtima akademskog grafičara Eugena Seklera: „Grafika na zboru bila je dosta skromno zastupana. Od knjigotiskara i litografija, koje su na Zboru izložile svoje proizvode, u prvom redu valja istaknuti Hrvatski štamparski zavod d. d. u Zagrebu. Njegov izlog svojom je estetskom i skladnom vanjštinom privlačio oko svakoga posjetnika stručnjaka. Iz izloženih grafičkih radova osobito su se isticali oni koji su izrađeni prema nacrtima akad. grafičara Eugena Seklera. Ukusno namješteni etažeri s djelima Dostojevskog i Almanahom Kraljevine Srba, Hrvata i Slovenaca stoje u lijepom skladu s glavnom vitrinom slobodnoga modernoga stila. Izlog je uredio sam akad. grafičar Eugen Sekler koji je time dokazao svoj istančani ukus. Cijeli je raspored učinio na nas dojam da bi izlog Hrvatskog Štamparskog Zavoda mogao s uspjehom prenositi slavu jugoslavenskog knjigotiskarstva i na svjetskim grafičkim izložbama. « ${ }^{15}$

$\mathrm{Na}$ visoko smještanje Eugena Seklera u okvire povijesti hrvatskoga grafičkog dizajna upućuje i njegova prisutnost na međunarodnim izložbama.

Eugen Sekler na popisu je izlagača u Katalogu paviljona Kraljevine SHS na Exposition internationale des arts décoratifs et industriels modernes (Međunarodna izložba dekorativnih umjetnosti) koja je 1925. godine održana u Parizu i na kojoj su predstavljena aktualna i raznorodna stremljenja u primijenjenoj umjetnosti. "Sve te ideje, stavovi, pristupi i pogledi o umjetnosti i umjetničkom djelu bili su na najbolji mogući način koncentrirani i sublimirani u Bauhausu, a javnosti prezentirani ovom izložbom, na kojoj je, između ostalog, inauguriran i pojam art deco. ${ }^{16} \mathrm{U}$ Parizu Sekler izlaže "Boîte en carton brodé, za Association de Femmes de Zagreb «. ${ }^{17} \mathrm{U}$ katalogu nema preciznijih podataka o predmetima koje izlaže, a uz njegovo se ime nalazi samo podatak da dolazi iz Zagreba.

Glavnu je ulogu u predstavljanju naše umjetnosti na toj izložbi imao Tomislav Krizman koji svojim grafičkim autoritetom i odabirom Seklera opravdava tezu o iznimnoj vrsnoći njegovih radova. Sekler je izlagao u odjeljku s radovima primijenjene grafike u Grand Palaisu, a tu su, među ostalima, bili izloženi radovi Tomislava Krizmana i Olge Höcker, tada prvih imena hrvatske tipografije i grafičkog oblikovanja. Glavno je nastojanje toga promotivnog nastupa Kraljevine SHS bilo »definirati vlastiti identitet kojega obilježava napetost između samosvijesti o nacionalnoj tradiciji i inzistiranja na suvremenosti ${ }^{18}{ }^{18}$

U članku Hrvatska knjižna umjetnost koji kao »bilješku uz osvrt na Internacionalnu izložbu knjižne umjetnosti u Leipzigu« 1927. godine za Grafičku reviju piše Artur Schneider, spominje se i Eugen Sekler. »Jugoslavenski odjeljak za izložbu je sastavio probranim i finim ukusom profesor Ljubo Babić« ${ }^{19}$ Schneider kao najznačajnije predstavnike hrvatske knjižne umjetnosti uz Babića ističe Tomislava Krizmana i Vladimira Kirina, a za Seklera kaže: »E. Sekler istaknuo se nekolikim uspjelim radovima u oblasti knjižne opreme. $\aleph^{20}$

$\mathrm{Na}$ Internacionalnoj izložbi knjižne umjetnosti u Leipzigu 1927. godine Sekler izlaže naslov Pola stoljeća šumarstva, 1876-1926. ${ }^{21}$ (sl. 6). Asketskim rješenjem korica dominira njegova vinjeta dekorativno stiliziranog žira.

U hrvatskim se muzejskim ustanovama nalazi samo jedan katalogiziran $\operatorname{rad}^{22}$ pripisan Eugenu Sekleru. Riječ je o tiskanici iz 1927. godine (sl. 7) pohranjenoj u Zbirci grafičkog dizajna Muzeja za umjetnost i obrt u Zagrebu. Ta je Seklerova tiskanica »u inventar muzeja dospjela zaslugom Ljube Babića, koji mu 1940. godine daruje svoje, ali i radove 


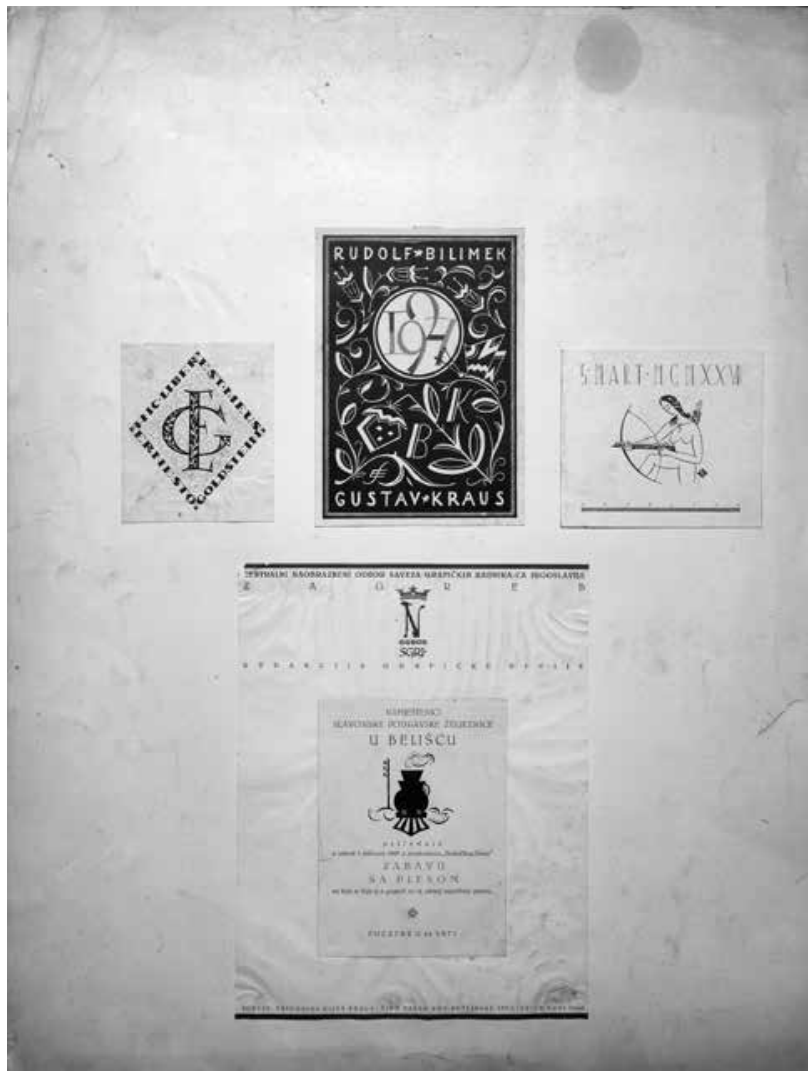

7. Eugen Sekler, tiskanica,1927. (MUO 07733) / Eugen Sekler, printed form, 1927, (MUO 07733)

svojih suvremenika iz područja grafičkog oblikovanja. Uz njegove, tu su i radovi s područja grafičkog dizajna Vladimira Kirina, Tomislava Krizmana, Eugena Seklera i Milivoja Uzelca. «"23 Babić je tom donacijom, kao i stručnim savjetima, dao temelje zbirci u nastanku - imao je »zamisao za to vrijeme vrlo suvremenog koncepta formiranja zbirke, koja bi svojim fundusom obuhvatila sve grafičke i knjigoveške tehnike, ali i povijesni razvoj grafičkog oblikovanja u ovoj sredini. $\ll^{24}$

Sekler je u zbirci predstavljen s pet tiskanica različite grafičke namjene koje su aplicirane na papirnu podlogu. Najranija je među njima ex libris za Ernesta Goldsteina - Hic liber est meus, koji se s obzirom na ranije publiciranje u Grafičkoj reviji (sl. 8) 25 $^{25}$ m̌e datirati u 1924. godinu. Ostale su četiri tiskanice iz 1927. godine.

Ex libris (sl.9) je koncipiran kao romboidna kompozicija koju uokviruje tekst Ernesto Goldstein - Hic liber est meus, a u središtu je upisan monogram $E G$. Razvedeno verzalno pismo karakterizira jak kontrast u debljini poteza te Sekleru karakterističan oštar i precizan rez. Inicijalima teče ornamentalna razlistana grana. Podloga je polja teksturirana razvedenim, jače stiliziranim linijskim ornamentom istog

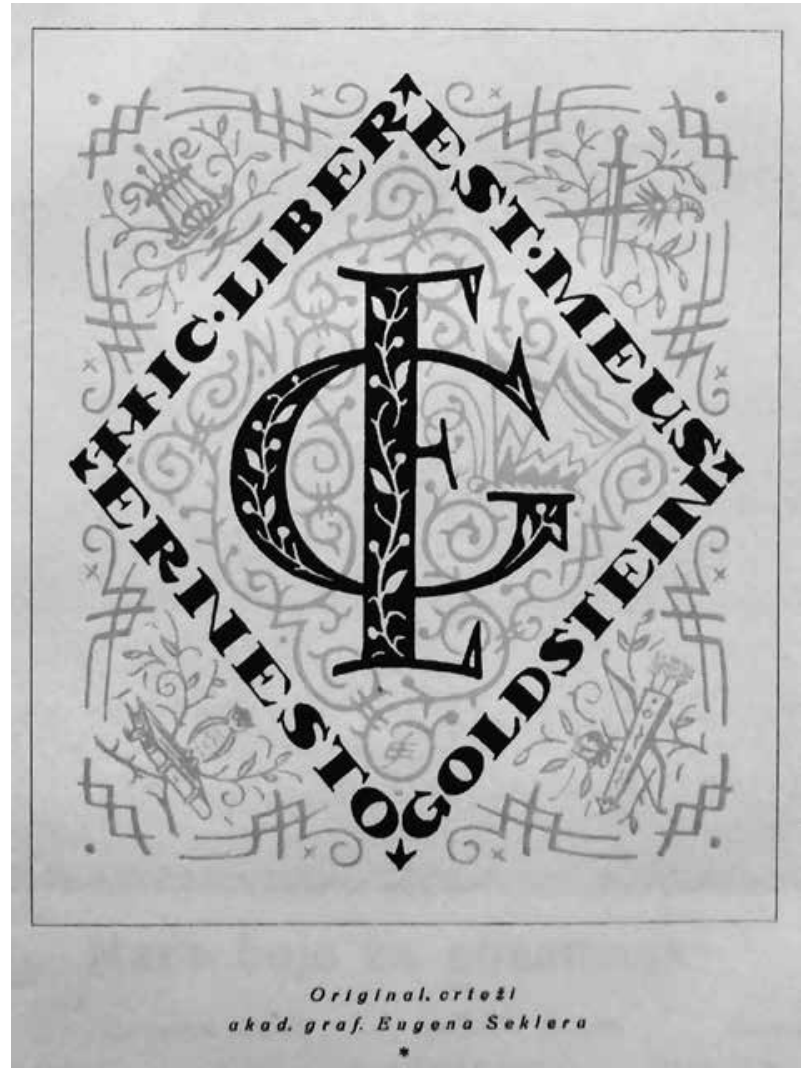

8. Eugen Sekler, ex libris: Ernesto Goldstein - Hic liber est meus, 1924., originalni crteži: prilog Grafičkoj reviji, 3 (1924.) (Muzej Slavonije Osijek) / Eugen Sekler, ex libris: Ernesto Goldstein Hic liber est meus, detail, 1924, original drawings: supplement to Grafička revija, 3 (1924) (Museum of Slavonia Osijek)

motiva koji prelazi u šaru, a prisutan je i motiv leptira koji je Sekler grafički razrađivao u autorskim vinjetama. Jednako je teksturiran i pravokutni segmentni okvir koji uokviruje romb koji se nalazi samo na otisku iz Grafičke revije. U

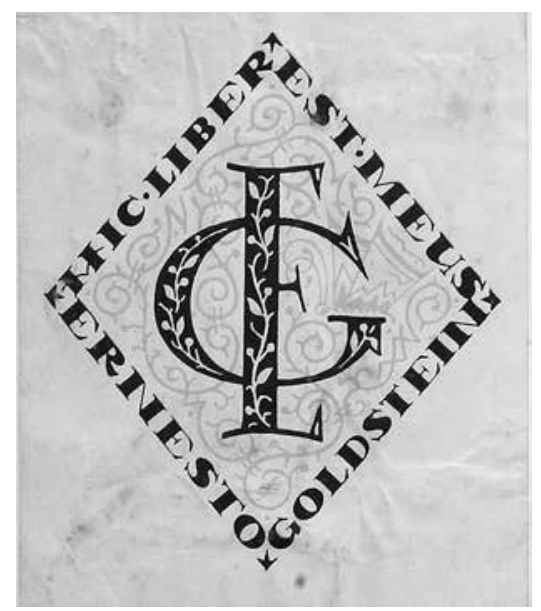

9. Eugen Sekler, ex libris: Ernesto Goldstein - Hic liber est meus, detalj, 1924. (MUO 07733) / Eugen Sekler, ex libris: Ernesto Goldstein - Hic liber est meus, detail, 1924 (MUO 07733) 


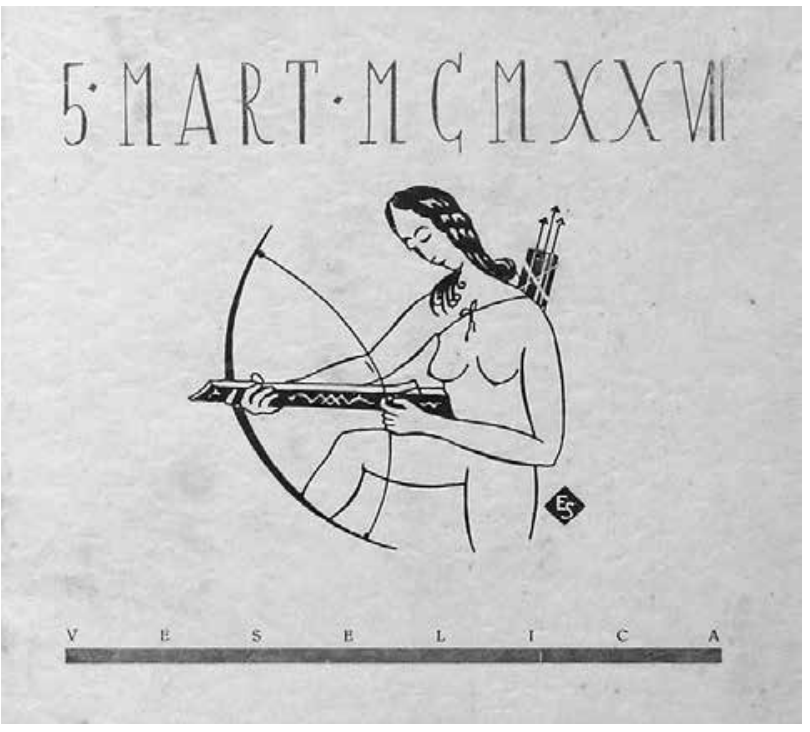

10. Eugen Sekler, naslovna stranica: 5 mart MCMXXVII VESELICA, detalj, 1927. (MUO 07733) / Eugen Sekler, cover page 5 mart MCMXXVII VESELICA, detail, 1927 (MUO 07733)

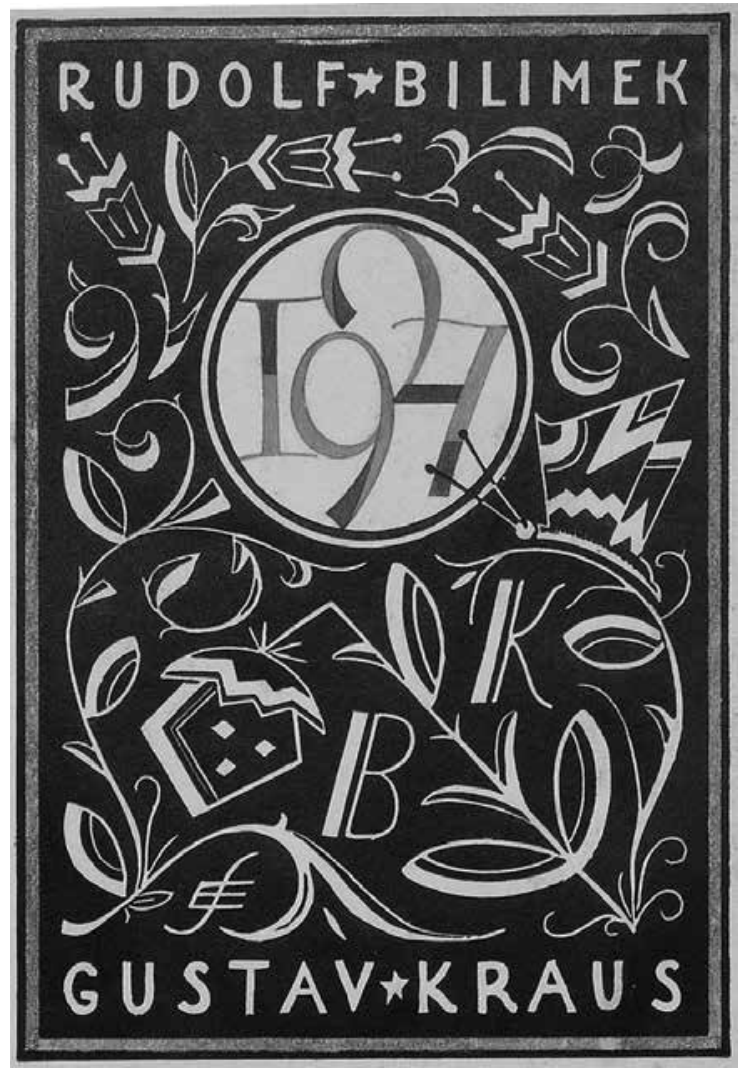

12. Eugen Sekler, naslovna stranica: Rudolf Bilimek - Gustav Kraus, detalj, 1927. (MUO 07733) / Eugen Sekler, cover page Rudolf Bilimek - Gustav Kraus, detail, 1927 (MUO 07733)

okviru su ucrtani harfa, sova koja sjedi na knjizi, ukrštene sablje te tobolac sa strijelama, kao simboli koji upućuju na osobnost vlasnika Ernesta Goldsteina. Na tom je rješenju zorna skicozna lakoća Seklerova crteža.

Izniman osjetilni, lirski koncept prisutan je u rješenju vezanom uz Veselicu iz 5. marta MCMXXVII (sl. 10) signiranom Seklerovim monogramom ES upisanim u romb. Crtež žene s lukom otvorenog je stiliziranog obrisa koji uz naglašenu gestikulaciju upućuje na vokabular art décoa.

Zatim slijedi signirani memorandum redakcije časopisa Grafička revija (sl. 11) s apliciranim Seklerovim logotipom Centralnog naobrazbenog odbora saveza grafičkih radnika-ca Jugoslavije. Pikturalni dio logotipa čini kruna ispod koje je stilizirana zmajolika figura koja formom odgovara početnom verzalu $N$, od naobrazbeni, a ispod koje je tekst: Odbor SGRJ. U logotipu se tako iščitava naziv vrhovne organizacije udruženja grafičara: Centralni naobrazbeni odbor Saveza grafičkih radnika-ca Jugoslavije. U sredini memoranduma nalijepljena je pozivnica za Zabavu sa plesom namještenika slavonske podravske željeznice u Belišću, iz dana 1. februara 1927. godine. Rješenje lokomotive blisko je konstruktivističkoj stilizaciji.

Posljednja je u nizu tiskanica naslovna stranica publikacije rađene za osječke industrijalce Rudolfa Bilimeka i Gusta-
11. Eugen Sekler, memorandum: redakcija časopisa Grafička revija; u sredini nalijepljena pozivnica za Zabavu s plesom namještenika slavonske podravske željeznice u Belišću, detalj, 1 . veljače 1927. (MUO 07733) / Eugen Sekler, letterhead: editorial board of the magazine Grafička revija; an invitation to the Dance party of employees of Slavonia-Podravina railway in Belišće glued in the centre detail, 1 February 1927 (MUO 07733) 
va Krausa (sl. 12). Pravokutnom, grafički zasićenom crnom plohom u negativu vijuga stilizirani linijski ornament, motiva razlistanog cvijeća, leptira i inicijala, koji dinamično teksturira plohu. Zaglađeni geometrizam i prenapregnuta stilizacija upućuje na artdécoovsko oblikovanje. Na klišeju je u prostor praznoga kružnog polja otisnuto godište 1927, istančanoga kolorističkog akcenta. Brojke su oblikovane u elegantnoj maniri art décoa, Sekleru svojstvenim oštrim, zaglađenim rezom.

Na svim se tim tiskanicama ogleda Seklerova fasciniranost slovnim znakovima koji su okosnica njegovih grafičkih koncepcija. Slovni su znakovi studiozno dinamički koncipirani, a Seklerov se rafinirani ukus ogleda u diskretnoj uporabi dekorativnih elemenata i pomnom odabiru boja.

\section{BILJEŠKE}

1 JASNA GALJER, Art deco u primijenjenoj umjetnosti i dizajnu, u: Art deco i umjetnost u Hrvatskoj između dva rata, katalog izložbe, (ur.) Miroslav Gašparović, Muzej za umjetnost i obrt, Zagreb, 2011., 23-59.

2 Zavičajnici grada Osijeka 1901.-1946., (ur.) Stjepan Sršan, Vilim Matić, Državni arhiv Osijek, Osijek, 2003., 728; u nastavku teksta: »Oženio se 1931. godine za Olgu rođenu Krajčić, no brak je 1939. godine razriješen, glasom uvjerenja nadrabinata jevrejske vjeroispovjesne općine u Osijeku.« Saznajemo, također, da je »Sekler vlasnik tiskare«, da je »sa židovske pokršten na rimokatoličku vjeru, i to 31. listopada 1941. godine u rimokatoličkoj župnoj crkvi Osijek I.«, te da »Eugen uživa zavičajno pravo u gradu Osijeku na temelju: zavičajnosti svoga oca Ljudevita«.

3 MARIJA MALBAŠA, Povijest tiskarstva u Slavoniji, Hrvatsko bibliotekarsko društvo, Zagreb, 1978., 48.

4 Akademie für graphische Künste und Buchgewerbe Leipzig, podatak iz Upisnog registra pohranjenog u Arhivu Akademije.

5 Saechsisches Staatsarchiv Leipzig: 20199 Staatliche Akademie für graphische Künste und Buchgewerbe, Leipzig: No. 136: Studentenakte; No. 56: Eintragung in der Stammrolle unter der lfd.; No. 7431; No. 217: Studentenkartei; No. 153: Anmeldebogen.

6 JEREMY AYNSLEY, Graphic design in Germany 1890-1945, Thames and Hudson, London, 2000., 47.

7 MARIJA MALBAŠA (bilj. 3), 48.

8 Vodič kroz arhivsku građu za fond, HR-DAOS-1371, TISKARA EUGEN SEKLER: »Promjena vlasništva nije nikada u registru provedena, samo što je odlukom br. 572 Gr R 133-04 od 27. II 1926. upisan kao prokurist sin vlasnika Eugen Sekler."

9 Uglavnom je odijeljeno poslovanje na ono koje drži Ljudevit odnosno kojem se u nazivu pojavljuje sljedeći opis: »Tiskara, knjigovežnica, Knjižara i papirnica«, ili »Umjetno knjigotiskarski zavod, knjigovežnica, knjižara, papirnica, pisaći i risaći pribori«, ili od 1935. godine »Povlaštena knjižara Kraljevine Jugoslavije, trgovina papira, pisaćeg i risaćeg pribora «. S druge strane, kada se u imenu pojavljuje Eugenovo ime, uvijek je riječ o »Tiskari«, a od 1932. godine u naziv je uključeno: "Grafički zavod i knjigovežnica«. Potpisnici tiskanica nekada su obojica, a uglavnom se izmjenjuju, s tim da Eugen uglavnom stavlja paraf pečatom $S$. E. \& O., što vjerojatno odgovara potpisu Sekler Eugen \& Ostali. Dakle, otac i sin simultano vode poslove, a čak nema razlike ni u karakteru narudžbi; uglavnom su to tiskarski poslovi vezani uz merkantilne tiskanice i razne trgovačke knjige. Kao adresa Tiskare, varira Desatičina ulica broj 5 ili broj 7.

10 MARIJA MALBAŠA (bilj. 3), 48.

11 Vidi ZLATA ŽIVAKOVIĆ-KERŽE, Od židovskog naselja u Tenji do sabirnog logora, Scrinia Slavonica: godišnjak Podružnice za povijest Slavonije, Srijema i Baranje Hrvatskog instituta za povijest, 6 (2006.),
497-514. Uhićenja i deportacije osječkih Židova započela su u kolovozu 1941., a intenzivirala se od lipnja 1942. godine. Tada su već bila oformljena dva sabirna mjesta za Židove iz grada i okolice i to na dvije lokacije; na dva sabirališna mjesta u osječkom Donjem gradu i u sabirnom logoru u Tenji. Otuda su Židovi odvođeni u koncentracijske logore Jasenovac i Auschwitz.

12 ZLATA ŽIVAKOVIĆ-KERŽE, Židovi u Osijeku (1918.-1941.), Hrvatski institut za povijest - Podružnica za povijest Slavonije, Srijema i Baranje, Slavonski Brod - Židovska općina Osijek, Osijek - Pauk, Cerna, 2005., 219.

13 URL: http://www.cendo.hr/BazaZrtavaDetalji.aspx?id=6776\&name $=$ sekler-eugen (1. 6. 2015.).

14 Vidi FRANJO MESAROŠ, Tipografski priručnik, Grafički obrazovni centar, Zagreb, 1985., 152; »Od svih umjetničkih pravaca s početka 20. stoljeća, ekspresionizam je imao najjači utjecaj na tipografsko stvaranje. Slovoljevaonice iznose na tržište nova pisma i ornamente s motivima koji odgovaraju zupčastim, zvjezdastim i 'eksplozivnim’ elementima ekspresivnog slikarstva i grafike. Smjer je to na koji i u tipografskom oblikovanju nailazimo nakon 1920. godine, a koji se ogleda u strogoj, simetričnoj kompoziciji koja je grafički krajnje pročišćena. Pri oblikovanju teksta, često nailazimo na retke svinute u luk ili na pretjerano spacionirane retke koji su ukrašeni prenaglašenom ornamentikom."

15 Vidi: -, III. Zagrebački zbor (Sajam uzoraka), Grafička revija, 5-6 (1924.), 79-80.

16 LADA KAVURIĆ, Hrvatski plakat do 1940., Institut za povijest umjetnosti, Nacionalna i sveučilišna knjižnica, Horetzky, Zagreb, 1999., 122. 17 Exposition internationale des arts décoratifs et industriels modernes: Section du Royaume des Serbes, Croates et Slovenes, Catalogue officiel, Girard et Bunino, Paris, 1925.

18 JASNA GALJER (bilj. 1), 42.

19 ARTUR SCHNEIDER, Hrvatska knjižna umjetnost: bilješke uz osvrt na Internacionalnu izložbu knjižne umjetnosti, Leipzig 1927., Grafička revija, 1-2 (1928.), 3-10.

20 Ibid., 7.

21 Pola stoljeća šumarstva, 1876-1926, Un demisiècle d'activité forestière, 1876-1926, Mémorial de l'Union forestière Yougoslavè à l'occasion de son cinquantenaire, Hrvatski štamparski zavod, Zagreb, 1926.

22 Inventarna oznaka tiskanice: MUO 07733, E. Sekler: tiskanica,1927.; Zagreb, Hrvatska.

23 Vidi JASNA GALJER, Ljubo Babić: iz zbirke grafičkog dizajna Muzeja za umjetnost i obrt, u: Ljubo Babić: radovi iz zbirki Muzeja za umjetnost i obrt, Muzej za umjetnost i obrt, Zagreb, 2001., 44-49.

24 Ibid., 44.

25 Originalni crteži: prilog Grafičkoj reviji, 3 (1924.).

\section{REFERENCES}

JEREMY AYNSLEY, Graphic design in Germany 1890-1945, Thames and Hudson, London, 2000.

CENDO. Istraživački i dokumentacijski centar. Žrtve i preživjeli: Eugen Sekler, URL: http://www.cendo.hr/BazaZrtavaDetalji. aspx?id=6776\&name=sekler-eugen $(01 / 06 / 15)$.

Exposition internationale des arts décoratifs et industriels modernes: Section du Royaume des Serbes, Croates et Slovenes, Catalogue officiel, Girard et Bunino, Paris, 1925.

JASNA GALJER, Ljubo Babić: iz zbirke grafičkog dizajna Muzeja za umjetnost i obrt, in: Ljubo Babić: radovi iz zbirki Muzeja za umjetnost i obrt, Muzej za umjetnost i obrt, Zagreb, 2001, 44-49.

JASNA GALJER, Art deco u primijenjenoj umjetnosti i dizajnu, in: Art deco i umjetnost u Hrvatskoj između dva rata, exhibition catalogue, (ed.) Miroslav Gašparović, Muzej za umjetnost i obrt, Zagreb, 2011, 23-59.

LADA KAVURIĆ, Hrvatski plakat do 1940., Institut za povijest umjetnosti, Nacionalna i sveučilišna knjižnica, Horetzky, Zagreb, 1999. 
MARIJA MALBAŠA, Povijest tiskarstva u Slavoniji, Hrvatsko bibliotekarsko društvo, Zagreb, 1978.

FRANJO MESAROŠ, Tipografski priručnik, Grafički obrazovni centar, Zagreb, 1985.

Pola stoljeća šumarstva, 1876-1926, Un demisiècle d'activité forestière, 1876-1926, Mémorial de l'Union forestière Yougoslavè à loccasion de son cinquantenaire, Hrvatski štamparski zavod, Zagreb, 1926.

ARTUR SCHNEIDER, Hrvatska knjižna umjetnost: bilješke uz osvrt na Internacionalnu izložbu knjižne umjetnosti, Leipzig 1927., Grafička revija, 1-2 (1928), 3-10.

-, III. [treći] Zagrebački zbor (Sajam uzoraka), Grafička revija, 5-6 (1924), 79-80.

ZLATA ŽIVAKOVIĆ-KERŽE, Od židovskog naselja u Tenji do sabirnog logora, Scrinia Slavonica: godišnjak Podružnice za povijest Slavonije, Srijema i Baranje Hrvatskog instituta za povijest, 6 (2006), 497-514.

ZLATA ŽIVAKOVIĆ-KERŽE, Židovi u Osijeku (1918.-1941.), Hrvatski institut za povijest - Podružnica za povijest Slavonije, Srijema i Baranje, Slavonski Brod - Židovska općina Osijek, Osijek - Pauk, Cerna, 2005.

Zavičajnici grada Osijeka 1901.-1946., (ed.) Stjepan Sršan, Vilim Matić, Državni arhiv Osijek, Osijek, 2003.

\section{ARCHIVAL SOURCES}

Akademie für graphische Künste und Buchgewerbe Leipzig, Arhiv, Upisni registar.

Saechsisches Staatsarchiv Leipzig: 20199 Staatliche Akademie für graphische Künste und Buchgewerbe, Leipzig: No. 136: Studentenakte; No. 56: Eintragung in der Stammrolle unter der lfd.; No. 7431; No. 217: Studentenkartei; No. 153: Anmeldebogen.

Vodič kroz arhivsku građu za fond, HR-DAOS-1371, Tiskara Eugen Sekler. 
Summary

\section{Marija Idžojtić}

\section{Printmaker and Graphic Designer from Osijek Eugen Sekler}

The paper presents a segment of the oeuvre of Eugen Sekler, a forgotten printmaker and graphic designer from Osijek educated at the Graphische Lehr- und Versuchsanstalt in Vienna and at the Akademie für graphische Künste und Buchgewerbe in Leipzig, where he studied under Professor Georg Belwe, a typographer and graphic designer highly renowned across Europe.

Sekler's example demonstrates that graphic design as a new discipline had its foundations in the printing trade, from which it detached due to the new demands of industry and mass media and in combination with the designer sensibility of certain individuals.

In the context of the history of Croatian graphic design, Sekler is distinguished not only by the quality of his education as a graphic artist, but also by his interest for the then still marginal areas of visual communications design which arose through collaboration between designers and industry - design of signs and logos, packaging and advertisements, as well as complete visual identities for craftsmen and industrialists in Zagreb and Osijek. He also made a significant contribution to the design of books and commercial vignettes. The modernist concept of Sekler's graphic design is evident in his concise expressionist graphic and typographic interventions, but it mostly corresponds to Art Deco vocabulary.

In Croatian museums there is only one catalogued work attributed to Eugen Sekler, preserved in the Collection of Graphic Design of the Museum of Arts and Crafts in Zagreb.

Eugen Sekler's prominent position in the history of Croatian graphic design is indicated by his participation in international exhibitions of applied arts - the Exposition Internationale des arts décoratifs et industriels modernes in Paris in 1925 and the International Book Fair in Leipzig in 1927. 